\title{
Iron fortification of dried skim milk and maize-soya-bean- milk mixture (CSM) : availability of iron in Jamaican infants
}

\author{
BY ANN ASHWORTH AND YVETTE MARCH \\ Tropical Metabolism Research Unit, \\ University of the West Indies, Kingston 7 , Famaica \\ (Received 20 March 1973-Accepted 5 Fune 1973)
}

\begin{abstract}
r. The availability of iron added to dried skim milk and to maize-soya-bean-milk mixture (CSM) was measured by whole-body counting in thirty clinically healthy children and compared with the availability of $\mathrm{Fe}$ from ferrous ascorbate alone.

2. The mean absorption of Fe added as ferrous sulphate to a test meal of dried skim milk was $9.5 \%$ when the test meal was given as a sweetened drink. When maize meal was added to the dried skim milk to produce a porridge the mean absorption of the supplementary Fe was reduced to $6.3 \%$. The mean absorption of Fe given as fertous ascorbate alone was $59.6 \%$.

3. These results differed from those reported for indirect tests done with animals in which the absorption of inorganic Fe added to milk-based feed preparations for infants was substantially greater than that of dietary $F e$.

4. The mean absorption of $\mathrm{Fe}$ added as ferrous fumarate to a test meal of maize-soyabean-milk mixture was $6.0 \%$, whereas that of $\mathrm{Fe}$ given as ferrous ascorbate alone was $63.5 \%$.

5. The amount of supplementary $\mathrm{Fe}$ added to maize-soya-bean-milk mixture (USA Department of Agriculture specification) was considered to be adequate.
\end{abstract}

In many countries there is a high incidence of iron deficiency among infants and young children of low social and economic status (WHO, 1972). Countries in the Caribbean area appear to be no exception although epidemiological data are limited. Fe-deficiency anaemia in Jamaican infants could result from the very poor absorption of Fe from maize, which is the staple food during early childhood (Ashworth, Milner, Waterlow \& Walker, 1973).

One of the more practical methods of eliminating Fe deficiency is by the supplementation of food with $\mathrm{Fe}$; therefore we have determined the availability of Fe added to two foods, namely dried skim milk and maize-soya-bean-milk mixture (CSM), which are widely distributed to infants and young children in numerous developing countries by international agencies such as UNICEF. CSM is a mixture of $70 \%$ maize, $25 \%$ defatted soya-bean flour and $5 \%$ dried skim milk and is supplemented with ferrous fumarate. Dried skim milk is not normally supplemented with Fe. The purpose of this study was to determine the availability of $\mathrm{Fe}$ added $(a)$ as ferrous sulphate to dried skim milk and $(b)$ as ferrous fumarate to CSM.

\section{METHODS}

Subjects

Thirty children were studied, of whom twenty-eight were clinically healthy children from an orphanage in Kingston and two were patients from the Tropical Metabolism Research Unit who had been treated for malnutrition and had recovered. Their ages 
ranged from 7 to 21 months although precise ages were not known for some of the abandoned children from the orphanage. Sixteen children received dried skim milk and fourteen received CSM.

Haemoglobin content $(\mathrm{Hb})$, packed cell volume (PCV), mean corpuscular haemoglobin concentration (MCHC), serum Fe, total Fe-binding capacity (TIBC), unsaturated Fe-binding capacity (UIBC), the percentage saturation of TIBC, and the white cell count were measured for each child by methods previously described (Wood, Milner \& Pathak, I968).

\section{Preparation of test meals}

The test meals were labelled extrinsically with ${ }^{59} \mathrm{FeCl}_{3}$.

Dried skim milk. Dried skim milk is distributed to infants and young children to provide a high-protein supplement. To be utilized efficiently this protein should be consumed with an additional energy source. We therefore investigated the availability of Fe added to test meals of dried skim milk when this was offered (I) as a sweetened milk drink and (2) as a porridge with maize meal providing the additional energy.

To prepare the sweetened milk drink $7 \mathrm{~g}$ dried skim milk (USA Food for Peace) and $\mathrm{II} g$ granulated sugar were dissolved in $50 \mathrm{ml}$ distilled water; $2.5 \mathrm{mg} \mathrm{FeSO}{ }_{4} \cdot 7 \mathrm{H}_{2} \mathrm{O}$ $(0.5 \mathrm{mg} \mathrm{Fe})$ were dissolved in $5 \mathrm{ml}$ distilled water and to this was added $0.1 \mu \mathrm{Ci}^{59} \mathrm{Fe}$. The labelled ferrous sulphate solution was added to the milk and the drink was thoroughly mixed and warmed before feeding.

To prepare the porridge the same amount of labelled ferrous sulphate solution was added to a mixture of $7 \mathrm{~g}$ dried skim milk, $\mathrm{I}$ I g sugar and $12.5 \mathrm{~g}$ maize meal in $225 \mathrm{ml}$ distilled water. The porridge mixture was then boiled in an aluminium pan for $15 \mathrm{~min}$ and allowed to cool.

CSM. CSM without the mineral premix was obtained from the USA Department of Agriculture, and $\mathrm{CaCO}_{3}$ and ferrous fumarate were added to comply with the USA Department of Agriculture specification for CSM $(5.9 \mathrm{rg} / \mathrm{kg}$ and $460 \mathrm{mg} / \mathrm{kg}$ respectively). To prepare the test meal $0.1 \mu \mathrm{Ci}{ }^{59} \mathrm{Fe}$ was added to $14.0 \mathrm{mg}$ ferrous fumarate $(4.6 \mathrm{mg} \mathrm{Fe})$ in ro $\mathrm{ml}$ distilled water. The labelled ferrous fumarate was then added to a mixture of $3 \circ \mathrm{g} \mathrm{CSM}$ and $15 \mathrm{~g}$ sugar in $250 \mathrm{ml}$ distilled water and the resulting porridge was boiled in an aluminium pan for $5 \mathrm{~min}$ and allowed to cool.

Ferrous ascorbate. Absorption of the Fe added to the two foods was compared with the absorption of $\mathrm{Fe}$ from ferrous ascorbate alone. Labelled ferrous ascorbate was prepared by adding $0^{\circ} \mathrm{I} \mu \mathrm{Ci}^{59} \mathrm{FeCl}_{3}$ to $5 \mathrm{ml}$ ferrous ascorbate solution containing $0.1 \mathrm{mg} \mathrm{Fe} / \mathrm{ml}$ (25 $\mathrm{mg} \mathrm{FeSO}_{4} \cdot{ }_{7} \mathrm{H}_{2} \mathrm{O}+3 \mathrm{I} \cdot 5 \mathrm{mg}$ ascorbic acid in $50 \mathrm{ml}$ distilled water). A fresh solution of ascorbate was prepared daily.

\section{Measurement of Fe absorbed}

For several weeks before the study began the orphanage infants did not receive supplements of Fe orally. Fe supplements given to the two infants from the Tropical Metabolism Research Unit were stopped at least $4 \mathrm{~d}$ before the tests started. All absorption studies were done after a $5-6 \mathrm{~h}$ fast, and the children were not fed for a further $3 \mathrm{~h}$ after the test had been completed. The ferrous ascorbate was given through 
a nasogastric tube and was washed through the tube with Io $\mathrm{ml}$ distilled water; the other test meals were taken orally.

The amount of radioactivity in each child was measured by whole-body counting in a 4 pi liquid scintillation counter (Garrow, 1965) using the counting procedure described by Ashworth et al. (I973).

\section{Sequence of tests}

The availability of the Fe added to dried skim milk was investigated in sixteen children. Each child was tested on three separate occasions, each I week apart, and the two test meals and the ferrous ascorbate solution were given in random order.

'The other fourteen children were each tested twice, with an interval of I week between tests, and the test meal of CSM and the ascorbate solution were given in reverse order to alternate subjects.

Testing was postponed if a child had fever or diarrhoea.

\section{RESULTS}

\section{Dried skim milk}

Table I shows the haematological pattern of each of the sixteen children tested and the individual values for $\mathrm{Fe}$ absorption. The mean absorption of $\mathrm{Fe}$ added as ferrous sulphate to dried skim milk was $9.5 \%$ when this was given as a sweetened drink. When maize meal was added the mean absorption of the supplementary Fe was reduced to $6.3 \%$, but this difference in availability was not statistically significant. The mean absorption of $\mathrm{Fe}$ from ferrous ascorbate was $59.6 \%$.

\section{CSM}

Table 2 compares the availability of $\mathrm{Fe}$ added as ferrous fumarate to test meals of $\mathrm{CSM}$ with the availability of $\mathrm{Fe}$ given as ferrous ascorbate to fourteen children. 'The mean absorption of the Fe added to CSM was $6.0 \%$, whereas that of ascorbate Fe was $63.5 \%$.

\section{Relationship between $F e$ status and absorption of $F e$}

The Fe status of the two groups of children was markedly different. Fifteen of the group of sixteen children were Fe-deficient (the criteria of Fe deficiency were serum Fe less than $500 \mu \mathrm{g} / 1$ and percentage saturation of 'IIBC less than $\mathrm{I}_{5}$ ), whereas none of the group of fourteen children was classified as Fe-deficient, but the haemoglobin contents of the two groups and the amounts of ascorbate Fe absorbed were similar. There was, therefore, no apparent relationship between the efficiency of $\mathrm{Fe}$ absorption and the plasma haemoglobin content, serum $\mathrm{Fc}$ concentration or percentage saturation of TIBC.

\section{DISCUSSION}

In formulating the test meals we attempted to provide the amounts of food a child might normally be expected to consume, and thus the results should be applicable to the home environment. In the first study we assumed that a child would normally 
\& है

จ.

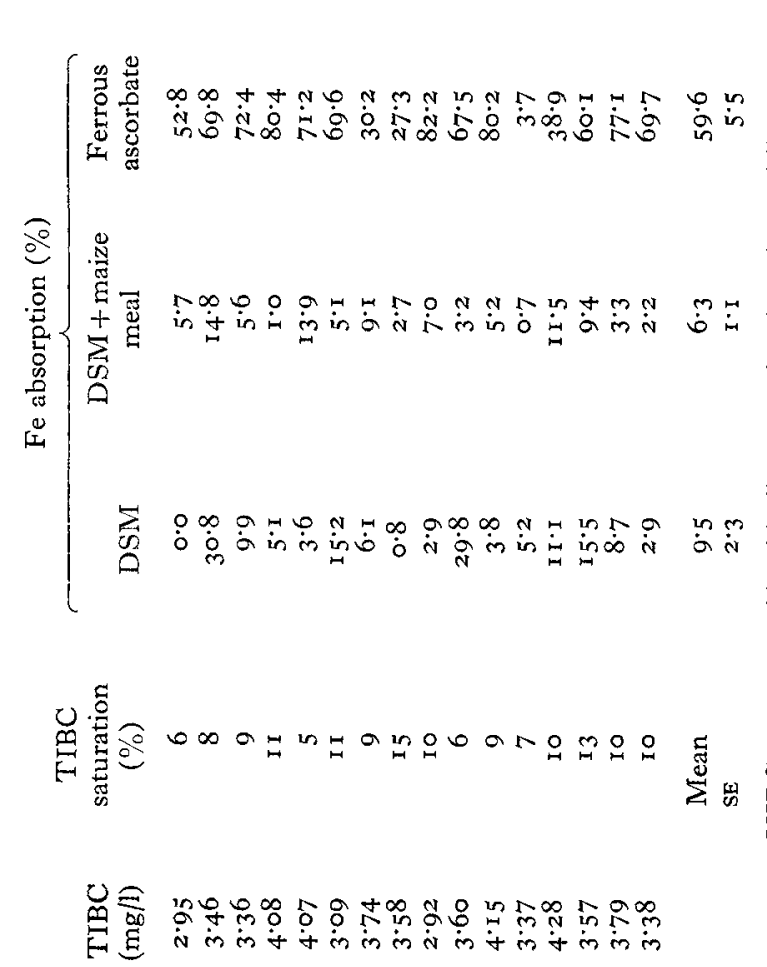

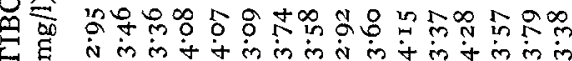

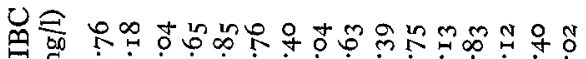

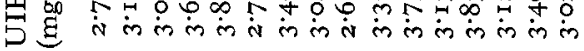
望

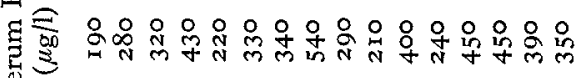
号

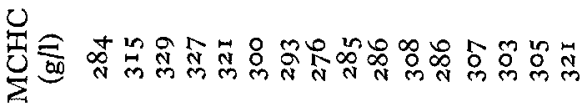

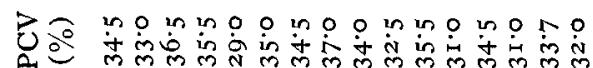


Vol. 30

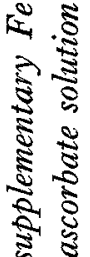

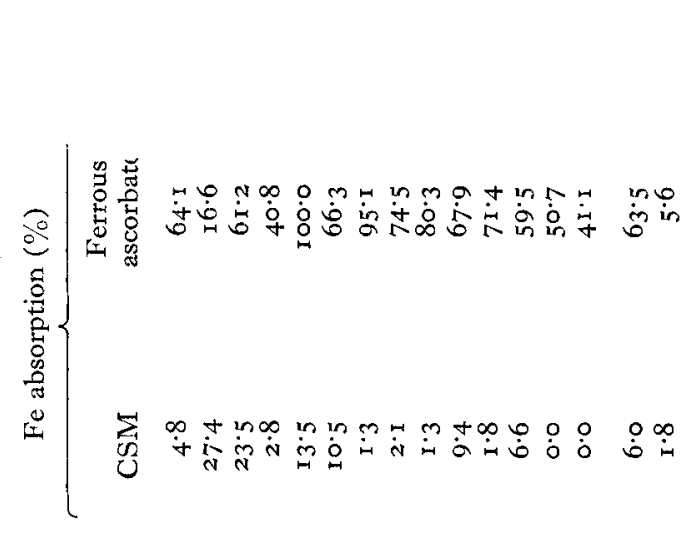

.

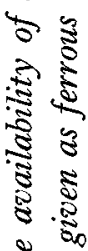

$\stackrel{2}{\pi}$

के

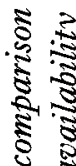

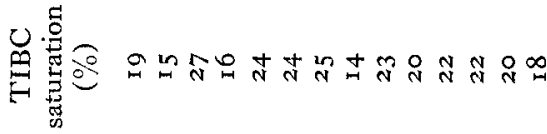

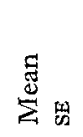

0

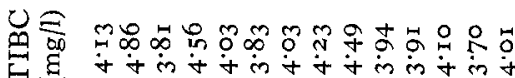

ริ

$\frac{2}{3}$

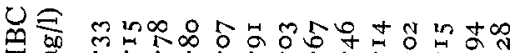

है ข

.

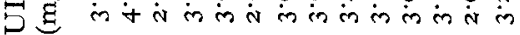

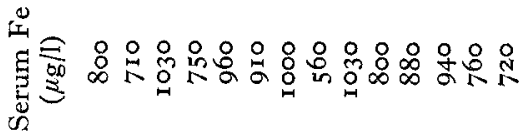

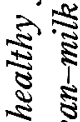

3)

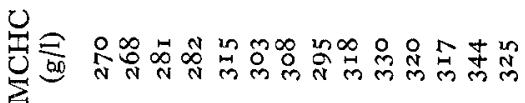

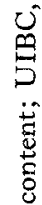

:

8ूँ

है

$\frac{3}{3}+\frac{5}{5}$

उ.

壱

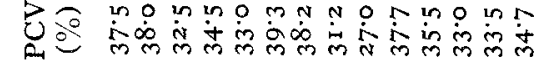

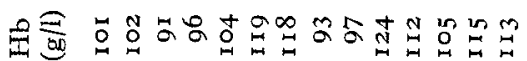

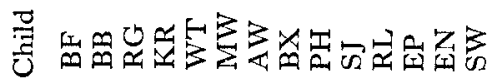


receive a milk drink five times a day and thus one-fifth of the daily dried skim-milk supplement allocated by the Jamaican Government was chosen for the milk-drink test meal, and for comparison this amount was used in the test meal of maize-meal porridge. In the second study the test meal of CSM conformed to the WHO/UNICEF guidelines for the use of CSM.

The Fe supplements added to the test meals of dried skim milk and CSM were different (ferrous sulphate and ferrous fumarate respectively). Although ferrous sulphate is cheaper, it has been shown to produce rancidity in cereals on prolonged storage and would therefore be unsuitable for Fe supplementation of CSM. The two Fe salts most frequently used to supplement milk preparations for infants are ferrous sulphate and sodium iron pyrophosphate. In food processing sodium iron pyrophosphate is relatively inert but the $\mathrm{Fe}$ is poorly absorbed by rats and chicks (Fritz, Pla, Roberts, Boehne \& Hove, I970; Pla \& Fritz, I970; Amine, Neff \& Hegsted, 1972) and there is some evidence that this is also true in man (Steinkamp, Dubach $\&$ Moore, 1955).

There have been very few studies in which the availability of Fe added to milk or cereals has been determined direct in young children. Schulz \& Smith (I958a) found that for six normal children given a milk drink supplemented with ferrous sulphate ( $30 \mathrm{mg} \mathrm{Fe}$ ) the mean value for $\mathrm{Fe}$ absorption was $6 \%$, whereas for two Fe-deficient children the mean value was $13 \%$. Stekel, Olivares \& Lopez (1972) found that in thirty-five infants aged $5^{-1} 7$ months the mean value for absorption of $\mathrm{Fe}(2 \cdot 5 \mathrm{mg} \mathrm{Fe})$ added to a low-fat milk preparation as ferrous sulphate was $6.9 \%$ compared with a mean value of $3.5 \%$ when Fe-supplemented whole milk was given. When $0.5 \mathrm{mg} \mathrm{Fe}$ was added as ferrous sulphate to test meals of dried skim milk with sugar and given to sixteen Fe-deficient infants we found the mean absorption of $\mathrm{Fe}$ was $9.5 \%$. The age and Fe status of our subjects were similar to those of the subjects of Stekel et al. (1972), and it is interesting that both studies show an apparent increase in Fe absorption as the fat content of the milk preparation decreases.

It has been suggested that $40-50 \%$ of the supplementary Fe in milk-based feeds for infants is absorbed (Theuer, Martin, Wallander \& Sarett, 1973). Their evidence is based on the results of indirect determinations of Fe availability calculated from the haemoglobin response of anaemic rats or chicks. The magnitude of the difference between $\mathrm{Fe}$ availability measured directly in infants or indirectly in test animals should give cause for much concern, as there has been an increase in the use of test animals for this type of investigation.

We found that when maize meal was added to the test meal of dried skim milk and sugar the mean availability of $\mathrm{Fe}$ in the supplementary ferrous sulphate was reduced to $6.3 \%$. Although the absorption of Fe from porridge was lower than that from dried skim milk when it was given alone, the absorption from the porridge was higher than that from maize meal given alone (Ashworth et al. 1973). This intermediate position may indicate the result of food interaction which has been shown to affect Fe availability (Layrisse, Martínez-Torres \& Roche, I968). The mean availability of $\mathrm{Fe}$ added as ferrous fumarate to the test meal of CSM was $6.0 \%$. The similarity of this value with that for the availability of $\mathrm{Fe}$ added as ferrous sulphate to the test meal of maize-meal 
porridge may be explained as maize meal is the major ingredient of CSM and also Fe absorption from the two salts when these are given alone is similar (Brise \& Hallberg, I962).

Our mean values of $6.3 \%$ and $6.0 \%$ for the absorption of $\mathrm{Fe}$ from $\mathrm{Fe}$-supplemented cereal preparations were lower than the mean value of $12.3 \%$ obtained by Schulz \& Smith (I958b) for seventeen normal children given rice, oatmeal or mixed cereal with supplements of sodium iron pyrophosphate $(3 \mathrm{mg} \mathrm{Fe})$, although the range of individual values for $\mathrm{Fe}$ absorption (o-25\%) was similar.

The variability in Fe absorption in our subjects may be the result of infection and fever which reduce Fe absorption to very low amounts (Beresford, Neale \& Brooke, 1971). Although no child was febrile when tested, we did not know whether any of the children had a febrile episode either before or after the tests. The results of white cell counts, which were undertaken to help identify children with subclinical infection, did not explain the very low $\mathrm{Fe}$ absorptions which were found in some instances.

The absorption of $\mathrm{Fe}$ from ferrous ascorbate was high. On previous occasions ferrous ascorbate was prepared fortnightly and stored at $4^{\circ}$ and, although no colour change was observed on storage, the values for $\mathrm{Fe}$ absorption were of the order of $20-30 \%$ (Ashworth et al. I973). As the values obtained with fresh ascorbate were consistently higher, we suggest that this test should be done under standard conditions.

In practical terms, the results indicate that the USA Department of Agriculture specification for Fe supplementation of CSM $(460 \mathrm{mg}$ ferrous fumarate $/ \mathrm{kg}$ ) is realistic and appropriate. WHO/UNICEF recommend 80-100 $\mathrm{g} \mathrm{CSM} / \mathrm{d}$ for children over $\mathrm{I}$ year of age, and this amount will furnish most of the protein required by a young child and approximately I $5 \mathrm{mg}$ supplementary $\mathrm{Fe}$. On the assumption that $6 \%$ of the $\mathrm{Fe}$ is available, the net amount of $\mathrm{Fe}$ absorbed will be $0.9 \mathrm{mg}$, i.e. $90 \%$ of the daily requirement estimated by WHO (I972). Ferrous sulphate contains $200 \mathrm{mg} \mathrm{Fe} / \mathrm{g}$ compared wit $\}_{2}$ $330 \mathrm{mg} \mathrm{Fe} / \mathrm{g}$ in ferrous fumarate. If the present allocation by the Jamaican Government of $35 \mathrm{~g}$ dried skim milk/d is to supply the equivalent of I $\mathrm{mg}$ absorbed Fe, then the amount of supplementary Fe required will be at least $1430 \mathrm{mg}$ ferrous sulphate $/ \mathrm{kg}$. Whether this high rate of supplementation may change the appearance or taste of the milk has not been investigated but such tests should be done before any Fe-supplementation programme is implemented to prevent problems of consumer acceptability.

We wish to thank the USA Department of Agriculture for supplying CSM without the mineral premix, the Matron and staff of the Children's Home for their co-operation, and Miss H. Gooden and Miss J. Wardle of the Haematology Department, University of the West Indies for technical assistance. The work was partly supported by a grant from the International Atomic Energy Agency. 


\section{REFERENCES}

Amine, E. K., Neff, R. \& Hegsted, D. M. (1972). F. agric. Fd Chem. 20, 246.

Ashworth, A., Milner, P. F., Waterlow, J. C. \& Walker, R. B. (1973). Br. F. Nutr. 29, 269.

Beresford, C. H., Neale, R. J. \& Brooke, O. G. (I97 I). Lancet i, 568.

Brise, H. \& Hallberg, L. ( 1962). Acta med. scand. r2r, Suppl. 376.

Fritz, J. C., Pla, G. W., Roberts, T., Boehne, J. W. \& Hove, E. L. (1970). J. agric. Fd Chem. 18, 647. Garrow, J. S. ( 1965$)$. W. Indian med. F. 14, 73.

Layrisse, M., Martínez-Torres, C. \& Roche, M. (r968). Am. J. clin. Nutr. 2I, II75.

Pla, G. W. \& Fritz, J. C. (r970). F. Ass. off. Analyt. Chem. 53, 79 I.

Schulz, J. \& Smith, N. J. (1958a). Am. $\mathscr{J}$. Dis. Child. 95, 120.

Schulz, J. \& Smith, N. J. (1958b). Am. F. Dis. Child. 95, I09.

Steinkamp, R., Dubach, R. \& Moore, C. V. (1955). Archs intern. Med. 95, I8I.

Stekel, A., Olivares, M. \& Lopez, I. (1972). Proc. int. Congr. Nutr. rx, Mexico City. (In the Press.)

Theuer, R. C., Martin, W. H., Wallander, J. F. \& Sarett, H. P. (I973). F. agric. Fd Chem. 21, $4^{82 .}$

Wood, J. K., Milner, P. F. \& Pathak, U. N. (1968). Br. F. Haemat. 14, I 19.

WHO (1972). Tech. Rep. Ser. Wld Hlth Org. no. 503. 